\title{
Analisis Sistem Pendidikan Di Sekolah Indonesia Kuala Lumpur (SIKL) : Perspektif Guru
}

\author{
Setyani \\ IAIN KUDUS \\ setyanisetyani377@gmail.com
}

Fina Zuliyana

IAIN KUDUS

zulianafina5@gmail.com

Rofitrasari

IAIN KUDUS

rofitrasari762@gmail.com

Nila Amelia

IAIN KUDUS

nilaaml411@gmail.com

\author{
Eva Luthfi Fakhrul Ahsani \\ IAIN KUDUS \\ evaluthfi@iainkudus.ac.id
}

\begin{abstract}
This study is to determine the education system in SIKL schools from the teacher's perspective, to determine the differences in the education system in SIKL and in Indonesia, to determine the barriers to education in SIKL, and to determine the role of teachers in the education system in SIKL. SIKL is an Indonesian school located in Kuala Lumpur. The uniqueness of SIKL is in feedback, progress, blue print and online. This study uses a qualitative research approach. The difference in the education system in SIKL and in Indonesia is one of them in the level of education. Barriers to education in SIKL are infrastructure, adsminitrative and documentary facilities. How to become a teacher or school principal in SIKL in a way. Must have extra patience. Due to limited infrastructure, excess working hours, the social environment is different from Indonesia, these are challenges that must be resolved by the teachers in SIKL. Obstacles in SIKL can be minimized by maximizing human resources and infrastructure.
\end{abstract}

Keyword: Education system, SIKL, teacher perspective.

\section{Pendahuluan}

Sistem pembelajaran ialah pembelajaran yang terdiri dari seluruh suatu yang saling berhubungan serta saling menolong satu sama lain. Sistem pembelajaran merupakan suatu yang berkaitan dengan pembelajaran buat menciptakan tujuan pembelajaran yang baik. Perihal ini berkaitan dengan sebagian faktor yang menyertai berhasilnya sesuatu tujuan suatu lembaga pembelajaran, mencakup partisipan didik, pendidik, kurikulum, serta wali murid. Sistem pembelajaran bisa berhubungan dengan proses pertumbuhan yang terdapat dalam warga, serta wajib berhubungan dengan pertumbuhan serta kebutuhan sesuatu negeri, sehingga guna dari suatu sistem pastinya jadi perihal yang sanggup merubah kultur, sosial, serta keilmuan, tentunya diiringi dengan kemampuan moral serta nilai- nilai yang sempurna (Daga, 2020). 
Pembelajaran dapat dikatakan selaku keunggulan proses belajar mengajar dengan pendekatan manusianya (man centered), serta bukan cuma semata- mata memindahkan otak dari kepala ke kepala ataupun alihkan mesin ke tangan, serta kebalikannya, lebih dari itu pembelajaran pula menjadikan manusia sanggup menaklukkan masa depan serta menaklukkan dirinya sendiri dengan tenaga pikir, serta tenaga ciptanya.

Sudut pandang dari masyarakat, pendidikan ialah proses sosialisasi, ialah memasyarakatkan nilai-nilai, ilmu pengetahuan, serta keahlian dalam kehidupan. pembelajaran ialah produk warga itu sendiri, ialah sanggup hidup tidak berubah-ubah menanggulangi ancaman serta tantangan masa depan (Mufida, 2018). "Adapun di SIKL sendiri memiliki pandangan bahwa kemajuan suatu negara tergantung dengan pendidikan generasi mudanya dan mereka juga memiliki paradigma bahwa keberhasilan seorang pelajar dipengaruhi oleh pendidik yang mengajar di sekolah”.

SIKL adalah lembaga pendidikan Indonesia yang berada di luar negeri, sekolah ini diperuntukkan untuk warga Indonesia yang berada di Malaysia. SIKL bisa dikatakan sebagai sekolah luar negeri terbaik karena menjadi SILN (Sekolah Indonesia Luar Negeri) pertama yang mendapatkan Akreditasi dari Badan Akreditasi Sekolah/Madrasah (BASM) pada tahun 2012. Perihal ini diakibatkan oleh sistem pembelajaran yang diterapkan di SIKL. Sistem pendidikan di SIKL bisa dikatakan selalu siap beradaptasi dengan perkembangan zaman sehingga mampu menjadi sekolah yang pemperoleh akreditasi dari BASM hidup manusia sangat dipengaruhi oleh perkembangan ilmu pengetahuan dan tekonologi.

Menurut Baharudin dikutip dari jurnal Budiman (Islam et al., 2017), teknologi data ialah pertumbuhan sesuatu sistem data yang mencampurkan antara teknologi pc dengan telekomunikasi. Sudah tidak asing lagi jika kecanggihan teknologi ikut andil dalam dunia pendidikan, apalagi perkembangan teknologi yang pesat di era globalisasi seperti saat ini tentu tidak bisa dihindari pengaruhnya pada dunia pendidikan ataupun dunia lainnya. "Pada lembaga-lembaga pendidikan di Indonesia ataupun di luar Indonesia tentu sudah banyak yang memanfaatkan teknologi".

Seperti halnya di Sekolah Indonesia Kuala Lumpur (SIKL). Lantaran masih banyak buku-buku pegangan atau buku lainnya yang belum ada secara lengkap, maka bukubuku tersebut di akses melalui kecanggihan teknologi. Tidak hanya itu saja, ada rancangan perencanaan pembelajaran (RPP) digital yang sudah digunakan disana.

Agar wali peserta didik maupun pendidik lebih mudah dalam memahami RPP tentu dibuatlah RPP digital di SIKL. Maka dari itu, kecanggihan teknologi sangat berperan penting dalam meningkatkan mutu pendidikan. Perkembangan teknologi juga menuntut kita untuk bisa menjadi lebih kreatif lagi dalam melakukan proses pembelajaran.

Perspektif merupakan metode melukiskan sesuatu barang pada permukaan yang mendatar sebagaimana yang nampak oleh mata dengan 3 ukuran panjang, lebar serta tingginya. "Perspektif guru adalah pandangan guru terhadap sistem pendidikan di SIKL. Penulisan karya ilmiah ini bertujuan untuk mengetahui keunikan sistem pendidikan di SIKL, untuk mengetahui perbedaan sistem pendidikan di SIKL dan Indonesia, untuk mengetahui hambatan pendidikan di SIKL, dan untuk mengetahui cara menjadi guru dan kepala sekolah di SIKL".

Oleh karena itu, dilakukan penelitian terhadap SIKL untuk mengetahui bagaimana sistem pendidikan dan seperti apa kualitas guru yang diterapkan di SIKL sehingga menjadikan SIKL sebagai sekolah Indonesia Luar Negeri yang pertama kali mendapatkan akreditasi dari BASM Nasional. selain itu, kami juga berharap 
penelitian ini dapat menjadi bahan evaluasi sekaligus memotivasi untuk lembaga pendidikan yang ada di dalam Negeri maupun di luar Negeri, agar bersama-sama bisa meningkatkan kualitas pendidikan di Indonesia. Belajar di rumah pada masa pandemi pemerintah menghimbau masyarakat agar melakukan sosial distancing dengan menerapkan sistem belajar daring agar memutus rantai penyebaran COVID 19 (Ahsani \& Mulyani, 2020).

\section{Metode}

Jenis penelitian yang digunakan penulis yaitu penelitian kualitatif. Pendekatan penelitian kualitatif adalah suatu proses penelitian dan pemahaman yang berdasarkan pada metode yang menyelidiki suatu fenomena sosial dan permasalahan manusia (Hasanah, 2017).

Pada riset ini, penulis membuat sesuatu cerminan yang lingkungan dengan mempelajari perkata, laporan yang terperinci dari sebagian pemikiran respoden serta melaksanakan riset pada suasana yang natural. Metode pengambilan informasi memakai Metode Focus Group Discussion (FGD) serta metode dokumentasi. Dimana pada metode pengambilan informasi lewat FGD ialah penulis mengadakan dialog bersama sebagian responden menimpa topik riset buat mengenali pemikiran ataupun uraian para responden.

Tujuan utama tata cara ini merupakan buat memeroleh interaksi informasi yang dihasilkan dari sesuatu dialog sekelompok responden dalam perihal tingkatkan kedalaman data menyingkap bermacam aspek kehidupan ataupun fenomena sehingga perihal tersebut bisa didefinisikan kejelasannya. Peneliti menggunakan teknik pengumpulan data dokumentasi dengan mengumpulkan data dan mencatat data-data yang sudah ada.

Teknik ini dapat diperoleh dari fakta yang tersimpan dalam bentuk surat, arsip, dokumen-dokumen, jurnal kegiatan dan sebagainya. Peneliti mencari data dari jurnaljurnal yang sudah ada sehingga mendapatkan hasil data yang akurat. Subjek dari penelitian ini adalah guru, siswa, kepala sekolah di SIKL.

Metode analisis data yang di guanakan pada penelitian di SIKL adalah menggunakan metode literatur yang mana pengumpulan data dengan cara membaca buku-buku, jurnal, dan situs internet.

\section{Hasil}

1. Sistem Pendidikan Sekolah Indonesia Kuala Lumpur

Sistem pendidikan yang dimiliki sekolah di Malaysia yaitu terkait dengan sistem kebahasaannya mewajibkan bahasa Inggis dan bahasa Melayu, sedangkan di Indonesia hanya mewajibkan bahasa Indonesa saja. Oleh karenanya sistem pendidikan di Malaysia seperti tersebut maka Sekolah Indonesia Kuala Lumpur juga mengikuti sistem tersebut.

Sistem yang berada di Sekolah Indonesia Kuala Lumpur sama dengan Indonesia yaitu memakai kurikulum Nasional, namun ada sedikit perbedaan karena adanya perbedaan geografis, SDA, dan sarpras namun masih mengutamakan atau mewujudkan cita-cita bangsa Indonesia. Pendidikan di Malaysia berada dalam penyelenggaraan pemerintahan federal. Sistem pendidikan Nasional meliputi pendidikan dari pra sekolah hingga perguruan tinggi.

Buat layanan pembelajaran di SIKL meliputi: Pembelajaran resmi: Pedidikan Anak Umur Dini, Halaman Anak-anak ( TK), Pembelajaran SD serta SMP, Pembelajaran 
SMA, Pembelajaran resmi pada rintisan sekolah Indonesia Johor Baru selaku sekolah Filal buat jenjang SD serta SMP. "Pembelajaran non-formal ataupun kesetaraan". "Pendidikan non-resmi yang di beri nama Pusat Pendidikan Warga Negara Indonesia (PPWNI) Di Klang, Program kejar maupun pendidikan kesetaraan berupa: Paket A buat jenjang Sekolah Dasar (SD), Paket B buat jenjang Sekolah Menengah Dini (SMP), Paket C buat jenjang Sekolah Menengah Atas (SMA), Pendidikan besar: SIKL yakni tempat buat mahasiswa Universitas Terbuka (UT) kelompok belajar Kuala Lumpur dan sekitarnya di bawah koordinasi UPBJJ UT Batam".

Peran orang tua sangat utama dalam masa pandemi ini karena orang tua harus mengawasi, membimbing, dan memberikan tugas kepada anak-anaknya supaya terus belajar meskipun sedang berada di rumah, saat belajar di rumah ada beberapa sistem yang digunakan: Feed back atau laporan orang tua kepada guru. Laporan di sini berisi tentang orang tua saat membimbing anak-anaknya belajar, dan dalam tahap ini orang tua juga bisa memberikan pertanyaan supaya diberi-kan arahan oleh guru wali yang mengampu anak, atau bisa dikatakan sebagai laporan hasil belajar siswa.

Untuk progress ini wali murid mengirimkan perkembangan anak saat melakukan belajar dari rumah. Cetak biru (Blue print) adalah perangkat kerja terperinci sebagai landasan dalam pembuatan kebijakan yang meliputi pemassangan program dan kegiatan serta implementasi yang harus dilaksanakan oleh setiap unit di lingkungan dinas.

Dalam hal ini seluruh guru harus sudah memberikan blue print atau gambaran, rancangan, tugas, materi, sistem penilaian, dan lain sebagainya atau bisa dikatakan dengan RPP kepada para orang tua atau wali siswa. Sekolah Indonesia Kuala Lumpur juga sudah mengunakan RPP digital, jadi akan semakin mudah di sampaikan secara online seperti saat pandemi seperti ini.

Online atau dalam jaringan (Daring) sudah pasti jika belajar di rumah itu mengunakan media online, yaitu guru memberikan semua materi dan tugas melalui media alat elektronik, dan materi tersebut akan dijelaskan melalu online pula juka ada hal-hal yang kurang dipahami siswa bisa bertanya langsung kepada guru atau kepada orag tua, di sinilah peran orang tua dalam menemani anaknya belajar di rumah.

Untuk cara belajar SIKL mengunakan google classroom, zoom meet, google meet, dan juga whatsapp group. Untuk saat ini karena pandemi sudah lumayan reda di Malaysia maka pihak sekolah sudah mulai melakukan belajar dengan tatap muka atau belajar di sekolah, akan tetapi tetap memperhatikan aturan protokol kesehatan yang telah ditetapkan oleh pemerintah dengan ketat, misalnya dengan jumlah siswa SD maka guru membagi menjadi dua rombongan belajar sesuai dengan kriteria.

Pertama, rombongan belajar A yaitu bisa disebut dengan rombongan belajar Loris, yaitu dimana rombongan ini hanya di isi oleh siswa yang ke sekolah dengan membawa mobil pribadi maka kondisi tersebut akan meminimalisir penyebaran virus covid-19. Kedua, yaitu rombongan belajar B yang bisa dikatakan sebagai rombongan Hairi yaitu dimana siswa yang lokasinya jauh dari sekolah dan berangkat ke sekolah mengunakan kendaraan umum.

Selanjutnya ada living curriculum di Sekolah Indonesia Kuala Lumpur (SIKL) tetap mengunakan sistem kurikulum Nasional tetapi tetap memperhatikan dan menyesuaikan kebutuhan para peserta didik. Untuk tingkat TK, SD kelas 1, 2, 3 ditiadakan ujian. Kemudian untuk sistem belajar di rumah siswa dituntut atau diajarkan lebih bertanggung jawab. 
Untuk hal-hal yang terkait dengan literasi Sekolah Indonesia Kuala Lumpur ( SIKL ) mengunakan budaya pegang buku dalam artian siswa diperkenalkan atau diajak membaca dengan buku secara lahiriah namun juga dibiasakan untuk membaca melalui media digital. Adapun untuk membaca digital sangat dibatasi karena dapat menyebabkan beberapa gangguan diantaranya kesehatan mata, tidak fokus dalam membaca, ketagihan dengan benda yang bernama hand phone (HP), maka guru di SIKL memiliki program literasi di antaranya; pojok literasi yang dimana satu hari minimal membaca buku selama 30-40 menit, perpus exploration, perpus exploration merupakan perpus pusat Negara Malaysia karena minat baca di Malaysia itu sanggat tinggi maka SIKL bekerja sama dengan perpustakaan pusat sebagai ajang memperluas ladang ilmu dalam membaca, dan kartu cinta baca, dimana di dalam kartu cinta baca tersebut terdapat tanda tangan orang tua dan wali kelas.

Setiap siswa setelah menyelesaikan satu buku dianjurkan untuk presentasi di depan wali kelas untuk mendapat tanda tangan dan sebelum presentasi siswa harus mendapatkan tanda tangan orang tua terlebih dahulu. Pada tahun 2011 pemerintah Indonesia juga mengirimkan mobil pintar dari Indonesia yang merupakan salah satu program Indonesia Pintar.

Bantuan tersebut diperuntukkan untuk pendidikan non-formal di Malaysia. "Dengan adanya perhatian dari pemerintah Indonesia ini menjadikan SIKL sebagai Sekolah Indonesia Luar Negeri pertama yang mendapat akreditasi dari pemerintah Indonesia.

\section{Perbedaan Sistem Pendidikan di SIKL dan Indonesia}

Sistem pendidikan yang berlaku di Negara-negara lain (Malaysia dan Indonesia), tentu Negara tersebut memiliki sistem pendidikan yang apik agar warga Negara tersebut dapat mencapai tujuan dari sistem pendidikan yang telah direncanakan dan menghasilkan hasil yang memuaskan. Sistem pendidikan di dua negara tersebut memiliki perbedaan antara satu level pendidikan dengan level lainnya (Haryanto, 2015).

Sehingga kita akan mengetahui apa saja perbedaan pada sistem pendidikan pada dua Negara ini. Sistem Pendidikan di Malaysia (SIKL) Pra Sekolah Dasar (Tadika) Beberapa lembaga pemerintahan, lembaga sukarela, dan lembaga swasta di Malaysia menyediakan lembaga pendidikan, yang diawali dari pra sekolah dasar yang diikuti oleh peserta didik mulai umur 4-6 tahun.

Secara keseluruhan, badan pendidikan pra sekolah terdaftar di departemen pendidikan dan secara umum badan pendidikan memakai bahasa melayu sebagai bahasa pendamping. Sekolah Dasar Sekolah dasar merupakan pendidikan yang harus diikuti oleh seluruh anak dari umur 7-12 tahun. Ada 2 macam sekolah dasar di Malysia yaitu, sekolah nasional untuk peserta didik dari Tamil dan Cina dan sekolah nasional untuk peserta didik melayu.

Tahap I mulai dari kelas I-III lebih menekankan pada dasar-dasar menulis, matematika dan membaca. Tahap II mulai dari kelas IV-VI lebih fokus pada pemanfaatan dan penguatan ketrampilan dasar yang dimiliki peserta didik dan akuisi pengetahuan.

Beberapa ujian diadakan untuk mengetahui penilaian pencapaian pengajaran yang diperoleh siswa antara lain: (PKBS) "Penilaian Kemajuan Berasaskan Sekolah yang dilakukan setiap tahun untuk mengetahui hasil pembelajaran dan menjadi pedoman bagi pendidik untuk membuat rencana peningkatan pada pendidikan lainnya".

"LDA (Level One Assessment) penilaian akan diujikan ketika siswa hendak menyelesaikan pen-didikan pada tahap I atau kelas III dari kemampuan dan potensi 
secara verbal, keterampilan dalam berpikir kuantitatif. UPSR (Ujian Penilaian Sekolah Rendah) akan diujikan pada akhir pen-didikan dasar. Materi yang akan diujikan adalah matematika, bahasa Melayu, bahasa Inggris dan ilmu pengetahuan”. Peserta didik melayu akan melakukan penilaian untuk pengambilan nilai pada pendidikan agama yang dilakukan selama proses belajar, biasa dikenal dengan PAPA (asas penilaian fardlu 'Ain). Sekolah Menengah Pertama Sekolah menengah dibagi menjadi 2 tahap yaitu, sekolah menengah bawah yang berlangsung selama 3 tahun dan sekolah menengah atas yang berlangsung selama 2 tahun.

Peserta didik dari jenis sekolah nasional (Tamil dan Cina) merujuk pada kelas perpindahan selama 1 tahun agar mempunyai cadangan bahasa melayu yang cukup dan peserta didik nasional dari Melayu dapat melanjutkan sekolah menengah atas. Adapun peserta didik yang mempunyai nilai baik pada tes pokok penilaian, secara langsung bisa mengikuti sekolah menengah pertama.

Peserta didik sekolah menengah pertama akan melakukan penilaian ujian (Lower Secondary Assessment Examination) di akhir tahun pendidikan. Sekolah Menengah Atas terdapat dua program pendidikan di sekolah menengah atas yang dapat dipilih oleh peserta didik, yaitu bidang akademik dan bidang kejuruan atau teknik.

Peserta didik pada bidang akademik akan melakukan tes ujian MCE (Certificate of Education), sedangkan peserta didik yang berada dibidang teknik atau kejuruan akan melakukan tes ujian MCV (Malaysia Certificate of Vocational) di akhir tahun masa pendidikan sekolah menengah atas. Pendidikan pasca sekolah menengah atas Untuk mempersiapkan masuk Universitas, peserta didik memiliki pilihan untuk melanjutkan pendidikannya antara 1 sampai 2 tahun setelah menyelesaikan sekolah menengah atas, untuk mendapatkan ujian matrikulasi dan sekolah from IV.

Pendidikan from VI diberikan untuk melengkapi persyaratan dari semua Unversitas, sedangkan pendidikan matrikulasi diberikan untuk melengkapi persyaratan pada Universitas tertentu melalui jalur khusus. Sekolah Tinggi Setelah peserta didik menyelesaikan sekolah menengahnya, kemudian peserta didik melanjutkan persiapan ujian yang diselenggarakan oleh lembaga ujian Malaysia dari beberapa Universitas lokal untuk mengikuti ujian sertifikasi sekolah tinggi Malaysia.

Bidang pendidikan tinggi meliputi universtas, politeknik, dan akademik. Beberapa program yang ditawarkan, mulai dari sertifikasi, degree levels dan diploma. Tingkatan pada sarjana pendidikan dijalani selama 3 sampai 4 tahun. "Sistem pendidikan di Indonesia pendidikan nasional di indonesia memiliki kemampuan membentuk watak dalam mencerdaskan kehidupan bangsa, bertaqwa kepada tuhan yang maha esa berahlak mulia, mandiri, kreatif untuk menjadi warga negara demokratis serta bertanggung jawab (Supendi, 2016)".

Prasekolah dari usia 3 tahun kanak-kanak di Indonesia umumnya tidak memiliki pendidikan formal dan di usia 3-5 tahun mereka memasuki taman kanak-kanak (TK). Tingkat pendidikan bagi warga negara Indonesia sangat wajib. Tujuannya yaitu untuk mempersiapkan anak didik untuk memasuki sekolah dasar (SD). Sekolah Dasar Pada usia 6-11 tahun anak memasuki sekolah dasar (SD). "Tingkat pendidikan sekolah dasar wajib bagi warga negara indonesia karena memiliki konstitusi nasional. Tidak seperti taman kanak-kanak yang sebagian besar diselenggarakan oleh pihak swasta (Ira, 2015). Akan tetapi sebagian besar sekolah dasar juga diselenggarakan oleh sekolah umum yang dipersiapkan oleh negara(sekolah dasar negeri).

Sama halnya sistem pendidikan di Ngara lain misalnya Malaysia, Australia, dan lainnya bahwa siswa wajib belajar selama 6 tahun untuk menyelesaikan proses belajarnya. Tetapi ada sekolah yang memberikan program belajar yang di percepat 
dimana siswa yang mempunyai intelektual lebih tinggi maka dapat menyelesaikan sekolah dasar hanya 5 tahun atau bisa kurang. Sekolah Dasar (SD) Sekolah menengah pertama (SMP) merupakan bagian pendidikan dasar di indonesia.

Setelah lulus dari SD, siswa dapat memilih untuk masuk MTs/SMP. Masa pembelajaran di SMP kisaran 3 tahun, dan setelah 3 tahun siswa dapat melanjutkan pendidikan di SMA, MA, atau SMK. Sekolah Menengah Atas (SMA) di negara Indonesia pada tingkatan SMA ini terdapat tiga jenis sekolah yaitu Madrasah Aliyah (MA), Sekolah Menengah Atas (SMA), dan Sekolah Menengah Kejuruan (SMK).

Madrasah Aliyah pada dasarnya sama dengan sekolah menengah atas yang lain, namun jatah kurikulum keagamaanya lebih besar dibanding dengan sekolah menengah atas. Siswa SMA dipersiapkan buat melanjutkan pendidikannya ke akademi besar, sebaliknya siswa Sekolah Menengah Kejuruan (SMK) dipersiapkan buat dapat langsung merambah dunia kerja tanpa melanjutkan pada tahapan pembelajaran berikutnya.

Pendidikan atau Perguruan Tinggi (Kuliah) setelah tamat dari Madrasah Aliyah atau Sekolah Menengah Atas (SMA) siswa dapat memasuki perguruan tinggi. "Perguruan tinggi di Indonesia ada dua jenis yaitu perguruan tinggi Negeri dan perguruan tinggi Swasta. Keduanya di pandu oleh kementrian pendidikan nasional. Terdapat beberapa kategori lembaga perguruan tinggi yaitu sekolah tinggi, akademi, universitas, politeknik dan institute"

Beberapa tingkatan gelar yang bisa diraih oleh mahasiswa antara lain S1, S2, S3, D3, D4. Hambatan yang dihadapi di Sekolah Indonesia Kuala Lumpur (SIKL). Setiap lembaga pendidikan pasti memiliki hambatan yang dihadapinya apalagi antar sekolah luar Negeri diantaranya Indonesia-Malaysia termasuk Sekolah Indonesia Kuala Lumpur.

\section{Hambatan yang Dihadapi di SIKL}

Di sini permasalahan atau hambatan yang dialami SIKL adalah dokumentatif, adsminitratif, dan sarana prasarana, maksud dari dokumentatif adalah siswa Indonesia yang bersekolah di SIKL harus memenuhi kelengkapan dokumen yang dibutuhkan dan setiap beberapa tahun sekali dokumen tersebut harus diperpanjang agar masih bisa sekolah disana (Mufida, 2018).

Sedangkan sarana prasarana di SIKL juga kurang memadai tidak seperti Indonesia yang sudah ada, seperti alat-alat trasional kesenian; gamelan, angklung, dll, sehingga menjadi hambatan bagi SIKL. Dan administratif juga berkaitan dengan dokumentratif tersebut yaitu untuk menyelenggarakan kebijakan untuk mencapai tujuan hambatan yang ada di Sekolah Indonesia Kuala Lumpur.

\section{Peran Guru Dalam Sistem Pendidikan}

Peran Guru dalam Sistem Pendidikan di SIKL Peran guru dalam pendidikan di SIKL di samping menjadi pendidik juga menjadi fasilitator, guru di sana juga menjadi oknum yang memperkenalkan budaya indonesia di negara tetangga. "Guru yang berada di SIKL merupakan Guru profesional yang mempunyai sertifikasi pendidik di pemerintah Indonesia dengan kompetensi meliputi pedagogik, kepribadian, sosial dan profesionalisme" (Mi, K et al., 2020).

Guru sebagai pendidik merupakan peran untuk memberi tugas atau bantuan dan memberi support untuk membuat anak menjadi disiplin agar anak menjadi patuh terhadap tata tertib di sekolah, norma hidup dalam keluarga dan masyarakat. 
Pembelajaran daring di laksanakan menggunakan aplikasi WhatsApp dan menggunakan aplikasi edukasi akan tetapi peran orang tua juga di butuhkan untuk mendampingi anak-anaknya dalam proses belajar daring. Kesimpulan Sistem yang berada di SIKL sama dengan indonesia yaitu memakai kurikulum Nasional.

Namun ada sedikit perbedaan karena adanya perbedaan geografis, SDA, dan sarana prasana. Sistem yang digunakan saat pandemi CIVID-19 yaitu feedback, progres, blue print, dan online. Perbedaan sistem pendidikan di Indonesia dan SIKL seperti halnya pada tingkat pendidikannya.

Hambatan di SIKL ini adalah pada administrasi, dokumentatif, dan sarana prasarana. Peran guru dalam di SIKL menjadi seorang pendidik dan fasilitator dan guru di sana menjadi oknum memperkenalkan budaya indonesia di negara tetangga (Kartadinata, 1996). Strategi orang tua dalam mengajar dan mendidik anak dalam pembelajaran At The Home masa Pandemi Covid-19.”

\section{Pembahasan}

\section{Sistem Pendidikan di Sekolah Indonesia Kuala Lumpur}

Sekolah Indonesia Kuala Lumour memiliki peran stategis untuk menjadi garda terdepan bagi Pendidikan di Malaysia dalam pembangunan Sumber daya Manusia Indonesia berdasarkan Pancasila dan Undang-Undang Dasar 1945. Berdiri sejak tanggal 10 Juli 1996, Sekolah Indonesia Kuala Lumpur berkiprah memberikan pelayanan Pendidikan pada Masyarakat Indonesia yang berada di Malaysia pada dasar Pendidikan Nasional. Sekolah Indonesia yang berada di SIKL mengemban peran untuk melestarikan, mempromosikan budaya Indonesia di tengah Masyarakat Malaysia.

Sebagai sekolah yang dinaungi oleh kedutaan Besar Republik Indonesia (KBRI) Sekolah Indonesia Kuala Lumpur (SIKL) juga menggunakan kurikulum yang berlaku di Indonesia. Layanan pendidikan untuk anak-anak Indonesia yang berada di Malaysia mengacu pada peraturan menteri luar negeri dan menteri pendidikan dan kebudayaan RI No.7 tahun 2015 dan No. 1 tahun 2015 tentang pengelolaan penyelenggaraan sekolah Indonesia di luar Negeri (Hasanah, 2017) ". Berangkat dari prinsip dunia dan kepercayaan dari konstitusi maka layanan bagi anak-anak Indonesia yang berada di Malaysia telah dimulai dari tahun 1969 melaluli penyelenggaraan SIKL.

Sekolah Indonesia Kuala Lumpur juga memberikan Pendidikan kepada Masyarkat di Malaysia dengan membuka Akses Pendidikan dengan program kejar paket A untuk jenjang Sekolah Dasar (SD), Paket B untuk jenjang Sekolah Mengenah Pertama (SMP), dan paket C untuk jenjang Sekolah Menengah Atas (SMA). Pada tahun 2012 Sekolah Indonesia Kuala Lumpur juga menjadi pusat belajar Universitas Terbuka di Kuala Lumpur untuk memenuhi kebutuhan pembelajaran di tingkat perguruan tinggi.

Pembelajaran warga dikerjakan oleh organisasi Bimbingan Buat Bangsa (EUB) bekerja sama dengan KBRI Kuala Lumpur serta LKBN ANTARA perwakilan Kuala Lumpur, kegiatannya antara lain pendidikan komputer, bahasa Inggris, serta kuliner Indonesia. Pendidikan bahasa dan seni budaya SIKL yakni sekolah yang berfokus pada 2 jenis kompetensi; pendidikan dan kebudayaan KBRI Kuala Lumpur".

Aktivitas tersebut meliputi: Lomba pidato bahasa Indonesia, workshop seni serta budaya Indonesia untuk siswa, serta mahasiswa Malaysia terdiri dari pelatiahan seni tari, seni musik gamelan, serta angklung. Menimpa kurikulum di SIKL sepanjang 
pandemi COVID-19 ini terdapat 2 jenis dalam proses belajar (Ahsani \& Mulyani, 2020). Awal, belajar di rumah buat belajar di rumah guru pula bekerja sama dengan wali murid dalam mengawasi partisipan didik. Kedua, belajar di sekolah.

\section{Perbedaan Sistem Pendidikan di SIKL dan di Indonesia}

Sekolah Indonesia Kuala Lumour memiliki peran stategis untuk menjadi garda terdepan bagi Pendidikan di Malaysia dalam pembangunan Sumber daya Manusia Indonesia berdasarkan Pancasila dan Undang-Undang Dasar 1945. Sebagai Upaya mengimbangi pesatnya perkembangan dunia Pendidikan dan ilmu pengetahuan sekolah yang berada di bawah naungan Kedutaan Besar Republik Indonesia Kuala Lumpur, senantiasa mengejar prestasi dan kualitas Pendidikan untuk kegiatan pembelajaran.

Sekolah Indonesia Kuala Lumpur menjadi pioneer yang patut di banggakan dalam berbagai ajang bergengsi seperti merai juara umum di lomba antar sekolah Indonesia luar negri dan jug aktiv dalam event-event yang di langsungkan di tingkat nasional. Di sekolah Indonesia Kuala Lumpur giat melakukan atau aktif mengikuti egiatan yang di laksanakan oleh sekolah-sekolah di Malaysia dan sekolah internasional yang berada di Kuala Lumpur.

Sistem Pendidikan di Indonesia yaitu menggunakan Sistem Pendidikan Nasional. Masyarakat Indonesia di tetapkan wajib belajar selama 12 tahun. Meliputi, 6 Tahun sekolah Dasar, 3 Tahun Sekolah menengah Pertama dan 3 tahun untuk sekolah menengah atas. System Pendidikan nasional bertujuan untuk mendidik dan memberikan pengetahuan secara akademis, keterampilan serta perilaku.

\section{Hambatan yang Dihadapi di SIKL}

Dari hasil penelitian yang didapatkan hambatan yang terdapat di SIKL yakni terkait dengan dokumentatif, admisistratif, dan sarana prasarana. Yang dimaksudkan dengan dokumentatif yaitu siswa yang bersekolah di SIKL harus memiliki dan melengkapi dokumen-dokumen sebagai syarat bersekolah di SIKL dan setiap beberapa tahun sekali harus diperpanjang atau diperbaharui, dalam hal ini siswa terhalang dengan pekerjaan orang tua yang tidak setiap waktu bisa pulang ke tanah air (Indonesia) dan memperpanjang doumen-dokumen yang dibutuhkan. Dan dokumen tersebut berkaitan dengan administrative untuk mengurangi hambatanhambatan yang ada.

Sedangkan untuk sarana dan prasarana, SIKL kurang memiliki alat ajar yang berkaitan dengan alat-alat tradisional Indonesia seperti gamelan, angklung, dll, hal ini dikarenakan tempat yang berada diluar Negara Indonesia.

\section{Peran Guru Dalam System Pendidikan}

Peran guru dalam lembaga pendidikan di SIKL disamping menjadi pendidik juga menjadi fasilitator, dan sebagai oknum yang memperkenalkan budaya Indonesia di Negara tetangga. Peran guru sebagai pendidik merupakan peran yang mampu memberikan tugas, pengarahan, dan pemahaman terkait pengetahuan, keagamaan, dan moral, serta memberi motivasi siswa untuk menjadi disiplin, patuh terhadap tata tertip disekolah, norma-norma dalam keluarga dan masyarakat.

Dimasa pandemic COVID-19 yang berlangsung cukup lama, berdampak pada semua sektor kehidupan tanpa terkecuali pendidikan. SIKL mengunakan aplikasi WhatsApp dan beberapa aplikasi edukasi yang ada. Saat menerapkan pembelajaran daring (dalam jaringan) SIKL berkerja sama dengna orang tua siswa untuk mendampingi dalam proses belajar daring. 
Proses pembelajran di SIKL dan Indonesia tidak memiliki banyak perbedaan, karena di SIKL juga menerapkan system kurikulum yang ada di Indonesia atau mengunakan kurikulum Nasional. Yang membedakan dalam system yang digunakan untuk menyampaikan pembelajaran di era pandemic COVID-19. SIKL mengunakan feedback yaitu tanggapan guru setelah memberikan materi kepada siswanya, progress, untuk progress ini wali murid mengirimkan perkembangan anak saat melakukan belajar dari rumah.

\section{Simpulan}

Cetak biru (blue print) adalah perangkat kerja terperinci sebagai landasan dalam pembuatan kebijakan yang meliputi pemassangan program dan kegiatan serta implementasi yang harus dilaksanakan oleh setiap unit di linkungan dinas. Dalam hal ini seluruh guru harus sudah memberikan blue print atau gambaran, rancangan, tugas, materi, sistem penilaian, dan lain sebagainya atau bisa dikatakan dengan RPP kepada para orang tua atau wali siswa. Sekolah Indonesia Kuala Lumpur juga sudah mengunakan RPP digital, jadi akan semakin mudah di sampaikan secara online seperti saat pandemi seperti ini.

Online atau dalam jaringan (Daring) sudah pasti jika belajar di rumah itu mengunakan media online, yaitu guru memberikan semua materi dan tugas melalui media alat elektronik, dan materi tersebut akan dijelaskan melalu online pula juga ada hal-hal yang kurang dipahami siswa bisa bertanya langsung kepada guru atau kepada orang tua, di sinilah peran orang tua dalam menemani anaknya belajar di rumah.

\section{Referensi}

Ahsani, E. L. F., \& Mulyani, S. E. (2020). The Implementation of Distance Learning Based E-Learning for Developing Student's Life Skills. Didaktika: Jurnal Pendidikan Sekolah Dasar, 3(2), 115-120.

Daga, A. T. (2020). Sekolah Dasar Di Malaysia , India Dan Indonesia. Edukasi Sumba (JES), 4, 24.

Haryanto, B. (2015). Perbandingan Pendidikan Islam Di Indonesia Dan Malaysia Comparison of Islamic Education in Indonesia and Malaysia. Adabiyah Jurnal Pendidikan Islam, 1(1), 79-96.

Hasanah, H. (2017). TEKNIK-TEKNIK OBSERVASI (Sebuah Alternatif Metode Pengumpulan Data Kualitatif Ilmu-ilmu Sosial). At-Taqaddum, 8(1), 21.

Ira, M. (2015). Sistem Pendidikan di Indonesia: antara keinginan dan realita. Jurnal Auladuna, 2(2), 233.

Islam, U., Raden, N., \& Lampung, I. (2017). Peran Teknologi Informasi Dan Komunikasi Dalam Pendidikan Haris Budiman. 8(I), 31-43.

Kartadinata, S. (1996). Kerangka Kerja Bimbingan dan Konseling Dalam Pendidikan Pendekatan Ekologis Sebagai Alternatif. 1-16.

Mi, K, Era, D. I., \& Janah. R. (2020). Peningkatan Counselor Competence Bagi Calon Guru A. 159-182.

Mufida, S. (2018). Upaya Pemerintah Indonesia dalam Menanggulangi Masalah Pendidikan Anak TKI di Serawak Periode 2014-2018.

Supendi, P. (2016). Variasi (Format) Sistem Pendidikan di Indonesia. Almufida, 1(1), $159-181$.

Budiman, H. (2017). Peran teknologi informasi dan komunikasi dalam pendidikan. AlTadzkiyyah: Jurnal Pendidikan Islam, 8(1), 31-43. 